\title{
Front Matter: Volume 11043
}

, "Front Matter: Volume 11043," Proc. SPIE 11043, Fifth Conference on Sensors, MEMS, and Electro-Optic Systems, 1104301 (24 January 2019); doi: $10.1117 / 12.2527340$

SPIE Event: Fifth Conference on Sensors, MEMS, and Electro-Optic Systems, SPIE. 2018, Skukuza, South Africa 


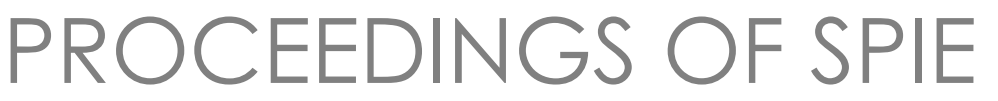

\section{Fifth Conference on Sensors, MEMS, and Electro-Optic Systems}

Monuko du Plessis

Editor

8-10 October 2018

Skukuza, South Africa

Organized by

University of Pretoria (South Africa)

Sponsored by

ECM Technologies (South Africa)

Solid State Technology (South Africa)

Horne Technologies (South Africa)

SAAB Technologies (South Africa)

HENSOLDT Optronics (Pty) Ltd. (South Africa)

Saetra (Pty) Ltd. (South Africa)

Published by

SPIE 
The papers in this volume were part of the technical conference cited on the cover and title page. Papers were selected and subject to review by the editors and conference program committee. Some conference presentations may not be available for publication. Additional papers and presentation recordings may be available online in the SPIE Digital Library at SPIEDigitalLibrary.org.

The papers reflect the work and thoughts of the authors and are published herein as submitted. The publisher is not responsible for the validity of the information or for any outcomes resulting from reliance thereon.

Please use the following format to cite material from these proceedings:

Author(s), "Title of Paper," in Fifth Conference on Sensors, MEMS, and Electro-Optic Systems, edited by Monuko du Plessis, Proceedings of SPIE Vol. 11043 (SPIE, Bellingham, WA, 2019) Seven-digit Article CID Number.

ISSN: 0277-786X

ISSN: 1996-756X (electronic)

ISBN: 9781510627529

ISBN: 9781510627536 (electronic)

Published by

SPIE

P.O. Box 10, Bellingham, Washington 98227-0010 USA

Telephone +1 3606763290 (Pacific Time) · Fax +1 3606471445

SPIE.org

Copyright (C) 2019, Society of Photo-Optical Instrumentation Engineers.

Copying of material in this book for internal or personal use, or for the internal or personal use of specific clients, beyond the fair use provisions granted by the U.S. Copyright Law is authorized by SPIE subject to payment of copying fees. The Transactional Reporting Service base fee for this volume is $\$ 18.00$ per article (or portion thereof), which should be paid directly to the Copyright Clearance Center (CCC), 222 Rosewood Drive, Danvers, MA 01923. Payment may also be made electronically through CCC Online at copyright.com. Other copying for republication, resale, advertising or promotion, or any form of systematic or multiple reproduction of any material in this book is prohibited except with permission in writing from the publisher. The CCC fee code is 0277$786 \mathrm{X} / 19 / \$ 18.00$.

Printed in the United States of America.

Publication of record for individual papers is online in the SPIE Digital Library.

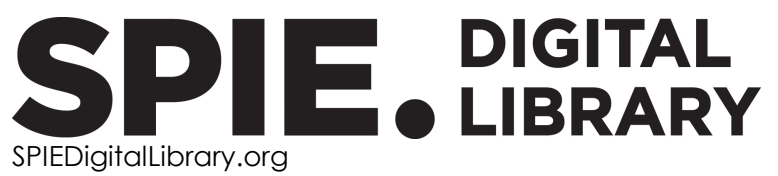

Paper Numbering: Proceedings of SPIE follow an e-First publication model. A unique citation identifier (CID) number is assigned to each article at the time of publication. Utilization of CIDs allows articles to be fully citable as soon as they are published online, and connects the same identifier to all online and print versions of the publication. SPIE uses a seven-digit CID article numbering system structured as follows:

- The first five digits correspond to the SPIE volume number.

- The last two digits indicate publication order within the volume using a Base 36 numbering system employing both numerals and letters. These two-number sets start with $00,01,02,03,04$, 05, 06, 07, 08, 09, 0A, OB ... 0Z, followed by 10-1Z, 20-2Z, etc. The CID Number appears on each page of the manuscript. 


\title{
Contents
}

\author{
vii $\quad$ Authors \\ ix Conference Committee \\ xi Introduction
}

PHOTONIC SUBSYSTEMS

1104302 Lanthanide activated phosphors for solar cell applications (Invited Paper) [1 1043-40]

NANOTECHNOLOGY

$1104303 \quad$ Nanoparticles and organic semiconductors for flexible electronics (Invited Paper) [1 1043-12]

1104304 Structural and luminescence properties of InAs0.94Sb 0.06 alloy grown via MOVPE [1 1043-25]

SILICON-BASED LIGHT EMITTING DEVICES

$1104305 \quad$ Figures of merit of avalanche-mode silicon LEDs [1 1043-34]

1104306 Investigation of light-emission and avalanche-current mechanisms in PureB SPAD devices [11043-41]

1104307 Light emission from Si avalanche mode LEDs as a function of E field control, impurity scattering, and carrier density balancing [11043-51]

1104308 Realizing micro- and nano-optical bio sensors on chip [11043-70]

1104309 Edge-emitting Si avalanche-mode LED integrated into a SiGe RF bipolar technology: optical power emission characterization with optical probe mapping technique [11043-79]

IMAGING TECHNOLOGY

11043 OA MWIR FPA control for optimal NETD [1 1043-31] 
11043 OB SWIR sensor design considerations [11043-36]

$110430 \mathrm{C}$ CMOS in-pixel optical pulse frequency modulator [1 1043-65]

\section{PRINTED ELECTRONICS}

11043 OD Biocompatibility in inkjet-printed paper-based microelectronic biosensors [1 1043-96]

11043 OE Printed electronics MIM capacitor for a microsystem power supply [1 1043-82]

11043 OF Electronic synthesis of printed resistor layout for a thermal petri dish incubator [1 1043-88]

11043 OG Characterization of inkjet-printed dielectric on different substrates [1 1043-69]

$11043 \mathrm{OH} \quad$ Development of a printed paper-based origami electrochemical sensor for the detection of heavy metals in water [11043-5]

11043 Ol Printed, flexible wireless temperature logging system [1 1043-19]

11043 0J Colorimetric system for paper-based assays [1 1043-86]

11043 OK CMOS floating-gate transistor in a heterogeneous printed electronics sensor module [1 1043-94]

$11043 \mathrm{OL} \quad$ Inductor design for inkjet-printed electronics [1 1043-83]

\section{INTEGRATED SILICON PHOTONICS}

11043 OM Design and simulation of optical micro-structures in silicon integrated circuitry with Si avalanche-mode light emitters, EXCEL optical ray tracing, and RSOFT optical simulation [11043-47]

11043 ON Design and optimization of compact silicon photonic sensors [1 1043-78]

PROCESSING OF DEVICES

1104300 Processing of and electrical properties of $\mathrm{ZnO}$ thin films and nanorods for sensor applications [11043-75]

11043 OP Doctor blade system for the deposition of thin semiconducting films [1 1043-32]

$11043 \mathrm{OQ}$ Effect of increasing etchant concentration to accelerate synthesis of $9-\mu \mathrm{m}$-long $\mathrm{TiO}_{2}$ nanotubes [11043-10]

iv 
11043 OR Structural, morphological, and optical studies of Rutile-phase $\mathrm{TiO}_{2}$ rods grown on $\mathrm{F}: \mathrm{SnO}_{2}-$ coated glass substrate by hydrothermal chemical bath deposition [11043-24]

\section{APPLICATIONS}

11043 OS Preparation and measurement ionizing radiation sensors with optical fibers [1 1043-73]

11043 OT Initial progress toward planar integrate, low-cost water vapour radiometers [1 1043-45]

11043 OU Earth observation of aerosols over inland water bodies in relation to calibration and validation of sentinel 2/3 [1 1043-71]

11043 OV Cooking harvested power manager for natural room cooling controller [1 1043-89]

11043 OW A low cost thermal energy absorber for rural Africa applications: isolation of high pressure and low pressure through heat exchanging [1 1043-49]

11043 OX Protection against transient overvoltage in precision AC-DC transfer measurement system [1 1043-26]

\section{OPTICAL SYSTEMS}

11043 OY Digital micro-mirror devices for laser beam shaping [11043-37]

$1104302 \quad$ Visible light communication using a software-defined radio approach [1 1043-48]

1104310 Silica optical fibers modify for measurement ionizing radiation [1 1043-72]

\section{NANOPARTICLES AND NANOSTRUCTURES FOR ELECTRONIC DEVICES}

$1104311 \quad$ NBTI in SiGe transistors [1 1043-22]

1104312 Inorganic p-channel thin-film transistors using CuO nanoparticles [1 1043-17]

1104313 Self-aligned organic thin-film transistors for flexible electronics [11043-18]

1104314 Improved organic thin-film transistor performance by dielectric layer patterning [1 1043-14]

1104315 Mechanical deformation on nanoparticle-based thin-film transistors [1 1043-58]

$1104316 \quad$ Oxygen detection with zinc oxide nanoparticle structures [1 1043-39] 
IMAGING DEVICES AND PROCESSING

1104317 Status quo and aspects to consider with ultraviolet optical versus high voltage energy relation investigations [11043-27]

1104318 Measurement of the thermal-vacuum defocus of an objective lens for an imaging payload on a CubeSat [1 1043-54]

1104319 The investigation of different image processing techniques to improve the visibility of volatile gas plumes in industry using optical gas imaging [11043-33]

\section{SPACE TECHNOLOGY}

11043 1A Flight hardware verification and validation of the K-line fire sensor payload on ZACube-2 [1 1043-100]

11043 1B Architecture for sensing of small clock shifts in Karoo telescope time on the MeerKAT GHz radio telescope [1 1043-93]

BIOSENSORS

11043 1C CMOS-based impedance spectroscopy for water quality monitoring [1 1043-92] 
Swart, H. C., 02

Tankio Djiokap, Stive R., OR

Temme, Julian, 13, 14

Truyts, A., OD

Twite, Monga F., OW

Urgessa, Zelalem N., OR

van Tonder, Vereese, 1B

van Zyl, Robert, 1A

Venter, Johan, OX

Vidor, Fábio F., 03, 12, 13, 14, 15

Viljoen, Johan W., OA, OB

Vollbrecht, Joachim, 14

Wagener, M. C., 04

Wagener, V., 04

Walker, J., 17

Walker, Shaunel, OT

Welz, Marc, 1B

West, N., 17

Willers, Cornelius J., OA

Wirth, Gilson I., 11, 15

Xu, Kaikai, 07

Zhang, Zhaotong, 07 


\title{
Conference Committee
}

\author{
Conference Chair \\ Christo Schutte, Denel Dynamics (South Africa) \\ Organizing Committee \\ Christo Schutte, Chair, Denel Dynamics (South Africa) \\ Monuko du Plessis, University of Pretoria (South Africa) \\ Trudi-Heleen Joubert, University of Pretoria (South Africa) \\ Jacobus van der Westhuyzen, Denel Dynamics (South Africa) \\ Thereza Botha, TechnoScene (Pty) Ltd. (South Africa)
}

Scientific Advisory Committee

Monuko du Plessis, Chair, University of Pretoria (South Africa)

Enrico Bellotti, Boston University (United States)

Somnath Bhattacharyya, University of the Witwatersrand

(South Africa)

Reinhardt Botha, Nelson Mandela University (South Africa)

Johan Burger, Square Kilometre Array (South Africa)

Ulrich Hilleringmann, Paderborn University (Germany)

Trudi-Heleen Joubert, University of Pretoria (South Africa)

Jan Korvink, Karlsruhe Institute of Technology (Germany)

Kevin Land, Council for Scientific and Industrial Research

(South Africa)

Wilhelm Leuschner, University of Pretoria (South Africa)

Andrew Marshall, Lancaster University (United Kingdom)

Dieter Mellett, Consultant (South Africa)

Walter Meyer, University of Pretoria (South Africa)

Tinashe Mutsvangwa, University of Cape Town (South Africa)

Bonex Mwakikunga, Council for Scientific and Industrial Research

(South Africa)

Willem Perold, Stellenbosch University (South Africa)

Jurriaan Schmitz, University of Twente (Netherlands)

Christo Schutte, Denel Dynamics (South Africa)

Lukas W. Snyman, University of South Africa (South Africa)

Viranjay Srivastava, University of KwaZulu-Natal (South Africa)

Hendrik Swart, University of the Free State (South Africa)

Douw van der Merwe, Azoteq (South Africa)

Robert van Zyl, Cape Peninsula University of Technology (South Africa)

Nelis Willers, Council for Scientific and Industrial Research

(South Africa)

Kaikai Xu, University of Electronic Science and Technology (China) 
Program Committee

Monuko du Plessis, Chair, University of Pretoria (South Africa)

Trudi-Heleen Joubert, University of Pretoria (South Africa)

Thereza Botha, TechnoScene (Pty) Ltd. (South Africa)

Session Chairs

1 Photonic Subsystems

Monuko du Plessis, University of Pretoria (South Africa)

2 Nanotechnology

Reinhardt Botha, Nelson Mandela University (South Africa)

3 Silicon-Based Light Emitting Devices

Lukas W. Snyman, University of South Africa (South Africa)

$4 \quad$ Imaging Technology

Bonex Mwakikunga, Council for Scientific and Industrial Research

(South Africa)

$5 \quad$ Printed Electronics

Trudi-Heleen Joubert, University of Pretoria (South Africa)

$6 \quad$ Integrated Silicon Photonics

Lukas W. Snyman, University of South Africa (South Africa)

$7 \quad$ Processing of Devices

Jan Korvink, Karlsruhe Institute of Technology (Germany)

8 Applications

Wilhelm Leuschner, University of Pretoria (South Africa)

9 Optical Systems

Johan Burger, Square Kilometre Array (South Africa)

10 Nanoparticles and Nanostructures for Electronic Devices

Ulrich Hilleringmann, Paderborn University (Germany)

11 Imaging Devices and Processing

Jacobus van der Westhuyzen, Denel Dynamics (South Africa)

12 Space Technology

Robert van Zyl, Cape Peninsula University of Technology (South Africa)

13 Biosensors

Willem Perold, Stellenbosch University (South Africa) 


\section{Introduction}

The 5th South African Conference on Sensors, MEMS and Electro-Optical Systems (SMEOS 2018) was held 8-10 October 2018 in Skukuza, the main rest camp in the Kruger National Park, South Africa. Sensors and electro-optical systems are technologies with many applications worldwide and are also identified as such by the South African government through the Departments of Science and Technology.

The aim of SMEOS 2018 was to provide a common forum for international researchers and developers to exchange information about their latest research findings, ideas, developments and applications in all areas pertaining to design, fabrication, and application in the fields of interest to SMEOS 2018. This is a relatively small field of expertise in South Africa and working together with international colleagues is of the utmost importance.

Monuko du Plessis 
Proc. of SPIE Vol. 11043 1104301-12

Downloaded From: https://www.spiedigitallibrary.org/conference-proceedings-of-spie on 26 Apr 2023 Terms of Use: https://www.spiedigitallibrary.org/terms-of-use 